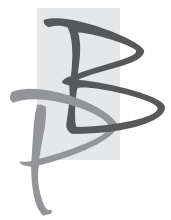

\title{
Od Inflant do Łotwy. Terytoria północne w ujęciu Mickiewicza
}

Streszczenie: Autor artykułu analizuje stosunek największego polskiego poety romantycznego, Adama Mickiewicza (1798-1855), do ziem dzisiejszej Łotwy. Badacz pokazuje kolejne etapy kształtowania się obrazu mieszkańców ziem rozciągających się nad Dźwiną: najpierw średniowiecznych Łotyszów, zagrożonych przez Zakon Kawalerów Mieczowych, potem mieszkańców Inflant Polskich, przynależnych od XVI do XVIII wieku do Rzeczypospolitej, „ludu fińskiego” okolic Rygi, w którym widzi Mickiewicz potencjał do wsparcia antyrosyjskiego powstania. Tekst pokazuje, jak Mickiewicz włącza Łotwę do swych koncepcji mesjanistycznej geopolityki i planów antycarskiego powstania.

Słowa-klucze: Adam Mickiewicz, Inflanty Polskie, Łotwa, Litwa, mesjanizm, powstania.

Jarosław Ławski - prof. dr hab., kierownik Katedry Badań Filologicznych „Wschód -Zachód" na Wydziale Filologicznym Uniwersytetu w Białymstoku. Autor m.in. monografii: Mickiewicz-Mit-Historia. Studia (Białystok 2010); Miłosz: ,, Kroniki” istnienia. Sylwy (Białystok 2014). Edytor Horsztyńskiego Juliusza Słowackiego w serii Biblioteki Narodowej oraz Pism rozproszonych Zygmunta Glogera. Członek Komitetu Nauk o Literaturze PAN; członek korespondent Polskiej Akademii Umiejętności. 


\section{From Livonia to Latvia. Northern territories as defined by Adam Mickiewicz}

Summary: The author of the article analyses the attitude of the greatest Polish Romantic poet, Adam Mickiewicz (1798-1855), to the lands of present-day Latvia. The author shows the successive stages of shaping the image of the inhabitants of these lands stretching over the Daugava River: first the medieval Latvians, threatened by the Order of the Brothers of the Sword, then the inhabitants of the Polish Inflanty (Livonia), who belonged to the Republic of Poland from the $16^{\text {th }}$ to the $18^{\text {th }}$ century, the "Finnish people" of the Riga area, in which Mickiewicz sees the potential to support the anti-Russian uprising. The text shows how Mickiewicz incorporates Latvia into his concepts of messianic geopolitics and plans for an anti-tsar uprising.

Key words: Adam Mickiewicz, Polish Inflanty, Latvia, Lithuania, Messianism, uprisings.

\section{Lotwy miało nie być...}

Projekt podejmujący temat relacji Mickiewicza do ważnych kultur XIX-wiecznej Europy, przedstawiający jego stosunek do „starych” narodowości i tych, które XIX-wieczna Europa dopiero rodzi, mógłby się, mówiąc brutalnie, obejść bez Łotyszów i Estończyków. Jeśli Litwini - jako nieodłączna część jagiellońskich wyobrażeń Rzeczypospolitej - byli stale w centrum uwagi poety ${ }^{1}$, to, zauważmy, raczej nie szukalibyśmy u niego wątków łotewskich czy estońskich. Już to dlatego, że pamięć historyczna Mickiewicza nie odnotowywała osobnej, kulturowej jakości, którą można by przypisać - stanowiącym w tym szkicu główny przedmiot zainteresowania -

1 Zob. J. Bachórz, ,Jak pachnie na Litwie Mickiewicza” $i$ inne studia o romantyzmie, Gdańsk 2003; J. Ławski, Staropruski tekst Adama Mickiewicza; J. Fiećko, Litwa w prelekcjach Adama Mickiewicza, [w:] Funkcjonowanie języków i literatur na Litwie. Litewsko-polskie zwiazki naukowe i kulturowe, red. M. Dawlewicz, I. Fedorowicz, A. Kalèda, Vilnius 2014; Między Wschodem a Zachodem. Europa Mickiewicza i innych. O relacjach literatury polskiej z kulturami ościennymi, red. G. Borkowska, M. Rudaś-Grodzka, Wrocław 2007. 
Łotyszom, już to dlatego, iż po prostu budzenie się łotewskiej świadomości narodowej przypadnie na połowę i końcówkę XIX wieku.

Czyżby więc nie było o czym mówić? Nie do końca. Jestem świadom rangi wielkich narracji historyczno-narodowych u Mickiewicza - polsko-litewskiej, niemieckiej, rosyjskiej, francuskiej, świadom narracji, które dopiero rozwijają się lub pozostają w stanie zalążkowym - rusińskiej, czeskiej, bułgarskiej, chorwackiej. Jeszcze bardziej jednak interesują mnie ujęcia wątków jakby pobocznych, pytań nieoczywistych; posługując się pomysłową terminologią, mógłbym powiedzieć, że w mickiewiczologii ma swe mocne miejsce odrębna także literacko „mikrologia”: tematy przeoczone, zalążkowe, ba, nawet obecne przez swą nieobecność! ${ }^{2}$

Lecz od razu pytam: co z tą Łotwą? Odpowiedź wydaje się godna przemyślenia, bo Mickiewicz, jak się okazuje, ma pełną świadomość przynależności dzisiejszych ziem łotewskich do I Rzeczypospolitej; co więcej, osobno widzi okres, gdy w całości należały one do tego państwa i czas, gdy po pokoju oliwskim $(1660)^{3}$ odpadła znaczna ich połać, zaś część wschodnia jako tzw. Inflanty Polskie na stałe weszła w skład państwa. Zatem to Inflanty są pojęciem opisującym, nazywającym, oznaczającym terytoria północne państwa polsko-litewskiego, które w projektowanej przez Mickiewicza formule miało się przekształcić w Rzeczypospolitą nie Dwojga, lecz Wielu Narodów. To temat osobny ${ }^{4}$. Kontynuując, owe Inflanty są u pisarza główną, lecz nie jedyną figurą geograficzną, kulturową, państwowo-historyczną opisującą terytoria naddźwińskie, gdyż wykształca się u niego pełna niedookreśleń, lecz zaznaczona odrębność łotewska.

Ujęcia Mickiewiczowskie oscylują między mitem politycznym Inflant i dyferencjacją etnojęzykową Łotyszów a geopolityczną oceną ziem nad Dźwi-

2 Nawiązuję do znanych propozycji metodologicznych Aleksandra Nawareckiego. Por. tegoż, Czarna mikrologia, [w:] Skala „,mikro” w badaniach literackich, red. A. Nawarecki, M. Bogdanowska, Katowice 2005, s. 9-24.

3 Por. Z dziejów stosunków Rzeczypospolitej Obojga Narodów ze Szwecją w XVII wieku, red. M. Nagielski, Warszawa 2007; J. Włodowski, K. M. Kantorska, Między wojna a pokojem - międzynarodowe implikacje i gwarancje pokoju oliwskiego 3 maja 1660 r., „Studia Gdańskie" 2011, T. XXIX, s. 183-203.

4 Piszę o tym [w:] J. Ławski, Mickiewicz - Mit - Historia. Studia, Białystok 2010, s. $165-203,378-398$. 
ną, niezwykle wysokim ich wartościowaniem jako areny przyszłych rozstrzygnięć militarnych XIX-wiecznej Europy.

W przypadku dużych, wykształconych nacji ich Mickiewiczowskie oceny charakteryzują się dużą polaryzacją, zawsze są zaskakujące, oscylują między bezlitosnym wydobyciem wad zbiorowości a określeniem jej wysokiej roli w planie celów historycznych ${ }^{5}$. Te cele mają wymiar mesjanistyczno-prowidencjalistyczny. Określa je kreator dziejów, Bóg, którego współpracownikiem jest mesjańsko świadomy człowiek. Na każdą kwestię narodową (i państwową) wieszcz Polaków patrzy z kilku, zazwyczaj niezmiennie tych samych perspektyw, które można określić tak:

- Stosunek narodu do chrześcijaństwa i jego kluczowych przełomów (między Rzymem a Bizancjum, katolicyzmem a protestantyzmem).

- Gotowość lub niegotowość do przyjęcia przez naród misji mesjańskiej powierzonej mu przez Stwórcę.

- Związek dziejowy (bezpośredni lub ideowo-mesjański) z dziejami Rzeczypospolitej, ujętymi jako jeszcze jeden, szczególny przejaw Boskiej misji.

- Związki z nowym podmiotem dziejów: Słowianami, pozostającymi w stanie wewnętrznej „,waśni” polsko-rosyjskiej.

- Aktywny bądź pasywny stosunek do imperatywu przekształcania świata (filozofia wolności, czynu, mesjanistyczna geopolityka czynu).

Perspektywa całościowa Mickiewicza - jako synteza wymienionych mikro- i subperspektyw - miała charakter teleologiczny i teologiczny, prowidencjalistyczny i mesjański, to z jednej strony. $Z$ drugiej, wydobywała element etniczno-kulturowy, który przyporządkowywała do konkretnej narodowości, jej misji, roli politycznej. Z trzeciej strony - o czym zapominają kreatorzy czarnego mitu mesjanizmu jako oderwanego od realiów typu irracjonalizmu o podłożu megalomańskim - taż perspektywa oglądu narodów była filozofią politycznej zmiany, geopolitycznych przetasowań, nowych sojuszy, czynów

5 Takie - skomplikowane i niejednoznaczne - są na przykład odniesienia Mickiewicza do kultury rosyjskiej i niemieckiej: E. Kiślak, Rosja w projekcie etycznym „Literatury stowiańskiej", [w:] Prelekcje paryskie Adama Mickiewicza wobec tradycji kultury polskiej i europejskiej, red. M. Kalinowska, J. Ławski, M. Bizior-Dombrowska, Warszawa 2011, s. 191-201; W. Próchnicki, Niemieckie tropy w „Panu Tadeuszu” Adama Mickiewicza, [w:] Noc. Symbol-temat-metafora, T. II: Noce polskie, noce niemieckie, red. J. Lawski, K. Korotkich, M. Bajko, Białystok 2012, s. 255-282. 
podejmowanych przez jednostki i zbiorowości. Miała więc bardzo konkretny wymiar polityczny, kreacyjny, nawet militarny.

Co ją odróżniało od późniejszych strategii politycznych, to mesjanistyczna idea. Z nią też związana była etyka czynu, walki, zmiany (w duchu chrześcijańska) ${ }^{6}$. Takie patrzenie na wielkie podmioty historii umożliwiało Mickiewiczowi niestandardowe ujęcia historii narodowych, które się dopiero zaczynały w XIX wieku (lecz na pewno nie polskiej), a nawet historii, które miały się dopiero zacząć, lecz już posiadały rozpoznawalne historycznie, kulturowo i geograficznie terytoria. Do takich należy - chyba intuicyjnie przez Mickiewicza wydobyta - historia Inflant, które w historycznych bólach staną się Łotwą.

\section{Inflanty}

W XIX wieku bierze początek kilka typów i sposobów opowiadania o ziemiach Pierwszej RP i ich dziejach, które trwają i przekształcają się aż do XXI wieku. Raz, popularne stają się opowieści swojaków, ,ziemlaków”, podróże swojaka po swojszczyźnie, przyjmujące wielogatunkową formę poematu, podróży, a nawet dramatu i listu. Dwa, rozwijają się narracje etnograficzno-historyczne (o wydźwięku też politycznym, od XVIII wieku7), które ulegają metamorfozie w kierunku coraz bardziej unaukowionych narracji historiograficznych ${ }^{8}$. Trzy, sporo znajdziemy podróży emigrantów lub obywateli odległych prowincji po nieznanych obszarach dawnej RP lub WXL (tu trzeba by też wliczyć teksty pisane przez cudzoziemców). Te narracje rozwiną się w osobliwy typ relacji, podróży, reportażu z ziem utraconych (żywy do dziś) ${ }^{9}$. Cztery, rodzi się narracja czysto

6 Zupełnie inną filozofię zmiany historycznej - nie rycerskiej, lecz okrutnej - prezentował Juliusz Słowacki. Por. A. Kotliński, Mistrz czerwonego rymu. Słowacki, Warszawa 2000; M. Bajko, Okrucieństwo ducha w „Królu-Duchu” Juliusza Stowackiego; M. Burzka-Janik, „Zagadnienie zła u Stowackiego” Anny Dziembowskiej. Przyczynek do eksplikacji okrucieństwa w „Królu-Duchu”, „Bibliotekarz Podlaski” 2017, nr 4 (XXXVII), s. 157-170 i 55-80.

7 Zob. J. A. Hylzen, Inflanty w dawnych owych y wielorakich aż do wieku naszego dzieyach y rewolucjach..., Wilno 1750.

8 G. Manteuffel, Inflanty Polskie, poprzedzone ogólnym rzutem oka na siedmiowiekowa przeszłość całych Inflant, Poznań 1879. Zob. też: B. Dybaś, Inflanty a polsko-litewska Rzeczypospolita po pokoju oliwskim (1660), [w:] Między Zachodem a Wschodem. Studia z dziejów Rzeczypospolitej w epoce nowożytnej, red. J. Staszewski, K. Mikulski, J. Dumanowski, Torun 2002.

9 Bardzo popularny typ reportażu rozwijający się w XIX wieku, potem po 1989 roku w prasie i Internecie. Por. Polska, Łotwa, razem, red. K. Kleina, P. Świątecki, Warszawa 2014; numer łotewski „Przewodnika Katolickiego” 1928, nr 36. 
użytkowa, informacyjno-przewodnikowa dla zupełnie nieznających zwiedzanych ziem podróżników ${ }^{10}$. Wszystkie te typy opowieści należałoby podzielić na bezpośrednie i skonstruowane.

Te pierwsze zasadzają się na bezpośredniej znajomości terenów, o których się pisze; te drugie zostają skonstruowane, wyobrażone przez pisarza bądź uczonego.

Piszę o tym wszystkim, by w końcu powiedzieć, że łotewska narracja Mickiewicza nie należy do żadnego z typów. Nie jest ani bezpośrednia, ani skonstruowana. Jeśli bowiem pokonamy w linii prostej przestrzeń od Nowogródka przez Wilno do Dyneburga i Rygi, zauważymy niezwykłe podobieństwo: krajobrazu, ethnosów (pomieszanie elementów słowiańskich z bałtyckimi), znaków pamięci historycznej i stylów sztuki (gotyk, neogotyk, barok). Ziemie inflanckie trudno więc nazwać prowincjami, których Mickiewicz zupełnie nie znał, choć po nich nie podróżował. Był przecież i w Wilnie, i w Petersburgu, znał pogranicza tego obszaru z obu stron: południowej (litewskiej) i północnej (rosyjskiej), znał bardzo wielu ludzi wywodzących się z Polskich Inflant, rosyjskiej części Inflant (głównie zruszczonych Niemców, poznał ich w Petersburgu). W ogóle był to swojski świat, podobnie jak na Litwie ukształtowany społecznie (dwór - wieś, lud - urzędnicy i arystokracja).

Cechą znamienną Inflant/Łotwy okaże się swoista pograniczność tego obszaru: to północny skrawek Rzeczypospolitej, historycznie podzielony, jakby „nasz” i „nie-nasz” - w części polskiej taki jak na Litwie, w części rosyjskiej grawitujący ku petersburskiemu centrum. I jeszcze jeden element: terytorialna, historyczna, językowa, społeczna pograniczność został tu jakby przecięta przez ostrą dystynkcję ludu i „panów”, szlachty. To z ludu powstaną w 2 połowie wieku nowe kultury narodowe, podczas gdy szlacheckie i arystokratyczne rody częściej wybiorą tożsamość polską, niemiecką, rosyjską lub (co rzadziej) podzielą się na rodziny, których przedstawiciele opowiadają się za jedną lub drugą opcją ${ }^{11}$. Lecz-nie rozmieniając tematu łotewskiego na szereg mniejszych i większych - sprawdźmy, czy Łotwa po prostu w ogóle pojawia się w pismach Mickiewicza...

10 Por. J. Cynarski, Łotwa współczesna, Warszawa 1925.

11 Trzeba jako przykład wymienić rodziny Platerów, Mohlów, Miłoszów, Bacewiczów, Doenhoffów, Romerów, Herbaczewskich (i wielu innych). 


\section{Słowa}

Uprzedzając wyniki, powtórzymy, że łotewskie ślady Mickiewicza wyprzedzają swój czas, ale nie należą do wymienionych typów narracji krajoznawczej. Jest to ujęcie człowieka wizji i czynu, erudyty i mesjanisty-profety, a w końcu także mesjanistycznego geopolityka. Zaglądając do Stownika języka Adama Mickiewicza, upewniamy się, iż leksyka związana z Łotwą nie jest obficie reprezentowana, lecz ma różnorodny charakter. Zaskoczeniem w ogóle jest pojawienie się w twórczości poety słowa Łotysze, i to wczesne, bo poświadczone przez pośrednictwo kroniki Macieja Stryjkowskiego:

Łotysz (1) im. wł. rz. m. $\diamond I m$. D. Łotyszów $\diamond$ Stryjkowski jeszcze widział [...] zabytki téj czci starożytnej u Łotyszów; GPrzyp 300-1 ${ }^{12}$.

Równocześnie należy podkreślić kontekst: Łotysz pojawił sie w aurze starości, starożytności, prawie takiej, w jakiej u Mickiewicza widzimy pokonanych, wyniszczonych, zgermanizowanych Prusów. Niewątpliwie tworzenie Grażyny (1823) i szczególnie Konrada Wallenroda (1828) stało się impulsem do żywego przemyślenia tematu Litwinów, Prusów i Łotyszów. Ci ostatni, co poświadcza Stownik..., pojawiają się u Mickiewicza jako Letowie w Przedmowie do Konrada Wallenroda, a potem w Historii polskiej pisanej już po 1834 roku:

Łotysze (3): Naród Litewski składający się s pokoleń Litwinów, Prussów i Lettów [...] wyzwany był do czynniejszego działania. KWP 1-4. towarzystwa uczone kształcą i pielęgnują dawną mowę Lettów pobratymców litewskich. KWP [279/6-7]. Na prawym boku Wisły siedziały [...] plemiona, obce Sławianom, Prusów, Letów i Litwinów HPol II 957-813.

Istotna jest konfiguracja - Lettów (Łotyszów) łączy Mickiewicz z bałtyckimi Prusami i Litwinami. Ich losy egzemplifikują dwie drogi historyczne, które Mickiewicz stale konfrontuje: droga sukcesu historycznego (Litwinów),

12 Słownik języka Adama Mickiewicza, red. K. Górski, S. Hrabec, t. I-XI, Wrocław 1962 1983. Wydanie oznaczam skrótem SJAM, po którym podaję numer tomu i stronę. Tu: SJAM, t. IV, s. 171.

13 SJAM, T. IV, s. 52. 
prowadzącą do stworzenia wspólnego państwa z Polakami; oraz droga całkowitej klęski, zniknięcia z areny dziejów (Prusowie, Jaćwingowie). Przy tym wszystkie trzy „pokolenia” (plemiona) „Narodu Litwinów” tworzą wspólnotę języka, kultury, dziejów. U Mickiewicza ma ona teleologię: utworzenie państwa Jagiellonów, Unię Lubelską (1569). Odróżniwszy Bałtów od Słowian (,obce Słowianom” plemiona), Mickiewicz zmierza od razu do zarysowania ich, Bałtów, perspektyw historycznych, a właściwie historiozoficznych. Polski poeta, co należy podkreślić, nie wyobraża sobie innego państwa Litwinów niż unijne czy federacyjne. Myśli tak nie z powodu „kolonizatorskich” zapędów, lecz kierując się geopolitycznym realizmem, kalkulacją (o czym na końcu) i pamięcią wspólnych doświadczeń polsko-litewskiej przeszłości. Na równi jest to dlań kwestia pamięci i kalkulacji.

Jaki w tym wszystkim los Lettów? Wydaje się, że młody pisarz jakby wahał się co do ich losu. Są oni zawieszeni między determinantą losu Litwinów (unia) a fatalizmem tragicznego losu Prusów (ich losy, na przykład dzieje Herkusa Monte, wodza powstańców pruskich w średniowieczu, przetwarza pisarz w Wallenrodzie $)^{14}$.

Około 1828 roku Lettowie (Łotysze) zdają się należeć do przeszłości. Ale to nie jest ostatnie słowo pisarza. Odnotujmy jeszcze dwa fakty: Słownik... przy haśle Łotwa odsyła do hasła Livonie $^{15}$. Liwowie, Liwonia synonimizują tu Łotyszów i Łotwę, choć trzeba podkreślić, iż chodzi w tym przypadku o lud ugrofiński z wybrzeży Bałtyku do dziś zamieszkujący śladowo do dziś ziemie łotewskie. Warto dodać, że u Mickiewicza pojawiają się też ziemie dzisiejszej Estonii w przymiotniku użytym w liście z 1843 (?) roku estoński:

ESTOŃSKI (1) przm. $\diamond$ Ip.ż.B. estońską $\diamond$

Zestawienie: gubernia estońska: Azali nie mógłbyś pożyczyć na dwa dni mapę jenerała Chrzanowskiego, zawierającą gubernią inflancką i estońską $L_{3} 508^{16}$.

14 Podobnie myślano na ziemiach polskich właściwie do końca XIX wieku. Zob. B. Obsulewicz, Zygmunt Gloger i Litwa, [w:] Funkcjonowanie języków..., s. 330-345.

15 Zob. J. Ławski, Staropruskie pierwowzory Konrada Wallenroda i Halbana, [w:] Romantyzm środkowoeuropejski w kontekście postkolonialnym, red. M. Kuziak, B. Nawrocki, Warszawa [2016], s. 397-425.

16 SJAM, T. II, s. 381. 
Jak Lettowie oznaczają Łotyszów, tak Estowie i bliżej nieokreślony „lud” służą Mickiewiczowi do wskazania tego, co jest związane z Estonią. I w tym przypadku widać wahanie nazewnicze - terminologia, którą znamy w XXI wieku, wtedy dopiero się tworzy.

Co oczywiste, język Mickiewicza najliczniej utrwala wspólnotę dziejów inflancko-polskich w słowach Inflanty, inflancki ${ }^{17}$. Można powiedzieć, że po „starożytnych” Letach to mieszkańcy polskich Inflant są jakby drugą odsłoną dziejów ziem nad Dźwiną. Przy tym perspektywa Mickiewicza jest tu szersza niż ta, która obejmuje Inflanty Polskie. Mickiewiczowskie Inflanty pojawiają się w dwu figurach - właśnie jako część Rzeczypospolitej i Wielkiego Księstwa Litewskiego (Inflanty Polskie) po 1830 roku (wiersz Śmierć Pułkownika) i jako Inflanty, strategiczna ziemia, o którą toczą spór Polska, Szwecja i Rosja, a która kolonizowana była od czasów średniowiecza przez żywioł niemiecki (Zakon Kawalerów Mieczowych) $^{18}$. I tutaj ujawnia się dominacja perspektywy historyczno-kulturowo-politycznej oraz mesjanistycznej. Znając poglądy Mickiewicza na rolę Niemców w dziejach oraz ich relacje z Rosją, nie będziemy zaskoczeni, odkrywszy passus ,inflancki”, pokazujący Inflanty jako najpierw pole starcia, a w końcu współpracy niemiecko-ruskiej już w czasach Iwana Groźnego (1530-1584). W prelekcjach paryskich (1840-1844) Mickiewicz przekonywał słuchaczy:

Iwan miał kilku zauszników wśród Niemców. Pierwszy to raz Niemcy występują w Moskwie jako pewna siłą. Moskwicini zawładnęli byli wieli miastami niemieckimi w Inflantach. Mieszkańców miast wziętych szturmem mordowano; ale niektóre z tych miast poddawały się. Później Moskwa, w myśl swej zwyczajnej polityki, znajdowała jakiś pozór, aby ludność ich uprowadzić i rozsiedlić po całym państwie. Jednakże Niemcy zdawali się niezbyt ubolewać nad tym oderwaniem od kraju. Przeciwnie, miłowali wielkiego kniazia, chętnie rozprawiali z nim o teologii. Wielki kniaź był otoczony teologami niemieckimi i zwierzał im się ze swych za-

17 SJAM, T. III, s. 93. Dodajmy, że SJAM nie odnotowuje, z oczywistych względów, licznych wątków inflanckich pojawiających się we francuskojęzycznych prelekcjach Mickiewicza w College de France.

18 Przypomnijmy, iż pełne nazwy Zakonu związane były z Liwonią: Fratures militae Christi de Livonia, Brüder der Ritterschaft Christi von Livland, zakon liwoński. Por. G. Manteuffel, O starodawnej szlachcie krzyżacko-rzymskiej na kresach inflanckich, Lwów 1910. 
miarów. Mówił im poufnie, że zamyśla inaczej urządzić państwo, że chce zacząć od wycięcia wszystkich bojarów, a było ich 400 000, potem wszystkich mieszczan, wrzecie części ludu prostego, a z resztą zrobi, co zechce. Niemcy, zamiast go od tego odwodzić, nie mając żadnego interesu w bronieniu Moskwicinów, pochlebiali jeszcze jego drapieżnym skłonnościom ${ }^{19}$.

W ten oto sposób u profesora Collége de France pojawia się idea bliskości czy nawet sojuszu dwóch żywiołów kulturowych: niemieckiego i rosyjskiego; apogeum tego sojuszu zobaczymy w XVIII wieku, kiedy niemiecka księżniczka Sophie Frederike Auguste von Anhalt-Zerbst jako Katarzyna II Wielka (1729-1796), caryca Rosji, dokona wespół z Prusami i Austrią rozbiorów Rzeczypospolitej. Mickiewicz rzuca świadomość tego faktu daleko w przeszłość - Inflanty stają się tu siedliskiem ,pewnej siły”, która uosabia ducha herezji (reformacja), imperializmu i ślepego posłuszeństwa. Nic tedy dziwnego, że panowanie nad Prusami i Kurlandią (potem całymi Inflantami) jest dla poety znakiem potęgi Rzeczypospolitej, a mówiąc precyzyjnie, potęgi królewskiej i geopolitycznego zabezpieczenia granic w terytoriach północnych:

Polski dwór królewski, jeden z najświetniejszych owego czasu, ciekawy przedstawiał widok. Udzielni książęta Prus, a później i Kurlandii, głosili się najpokorniejszymi sługami, wiernymi poddanymi króla. Przysięgali mu na klęczkach wierność na runku krakowskim. Hospodarowie wołoscy i mołdawscy bili czołem przez królem, gdy tymczasem panowie polscy i posłowie ledwie raczyli zdejmować czapkę w obecności swego monarchy ${ }^{20}$.

To znamienny fragment: przeciwstawia on siły państwa i króla rodzącemu się już w XVI wieku duchowi wolności szlacheckiej, który z kolei przeobrazi się w szlachecki anarchizm. Figura lenna Kurlandii i Prus synonimizuje tu osiągniętą potęgę, której zagrażają wyznaniowe podziały kraju. Mickiewicz wskazuje z jednej strony na pluralizm religijny, z drugiej na znaczenie kato-

19 A. Mickiewicz, Dzieła. Wydanie Rocznicowe 1798-1998, T. VIII: Literatura słowiańska. Kurs pierwszy, opr. J. Maślanka, przeł. L. Płoszewski, Warszawa 1997, wykład XXXI, s. 445-446. Por. W. A. Serczyk, Iwan IV Groźny, Wrocław 2004.

20 Tamże, wykład XXXII, s. 456. 
licyzmu, który dzięki królowi Stefanowi Batoremu i jezuitom staje się religią państwową. W imponującym rzucie wizyjnym, skrócie oratorskim pojawiają się także Finowie, Ryga, „lud fiński” (Estończycy). Co ciekawe, katolicyzm łączy poeta-prelegent z ludowym przywiązaniem do „dawnych tradycji”, charakteryzującym rzekomo mieszkańców Inflant:

W Koronie, to znaczy w Wielkopolsce i Małopolsce, pomimo walk religijnych król pokładał ufność w moc uczuć narodowych, nie widział tam żadnego niebezpieczeństwa; kraje te nie potrzebowały jezuitów. Natomiast na Litwie, gdzie wiodły jeszcze rej rodziny należące do Cerkwi wschodniej, na Białej Rusi, dokąd język polski jeszcze nie był przeniknął, zwłaszcza zaś w Prusiech, którym zagrażało plemię niemieckie, w Inflantach, pośród Finów i Niemców - wszędzie tam umieszczał jezuitów, jakby twierdze przeciw duchowemu wpływowi zagranicy. Akademie królewiecka i wileńska, kolegium w [Rydze], liczne kolegia i szkoły założone na Białej Rusi świadczą o zdumiewającej rzutkości króla.

W Inflantach zastał on ugruntowany już protestantyzm; szlachta była protestancka. Ale lud fiński nie wiedząc jeszcze, jakie dogmaty były przedmiotem sporów między sektami, trzymał się mocno dawnych tradycji. Król zrozumiał, że potęgę swą winien oprzeć na tym uczuciu. Starał się przywieść lud z powrotem do Kościoła katolickiego; tym sposobem odcinał szlachtę niemiecką od podstawy i zmuszał ją do szukania oparcia w Polsce ${ }^{21}$.

Jest to jeden z tych niezbyt licznych fragmentów, w których Mickiewicz z podziwem mówi o zakonie jezuitów. Wkrótce staną się oni żywiołem psującym państwo, rozbijającym je, jak był przekonany wieszcz. Widać, iż patrzył na te same zjawiska (Inflanty, jezuici) ze skrajnie różnych ujęć, lecz zawsze z punktu widzenia losów Rzeczypospolitej i jej misji mesjańskiej ${ }^{22}$. Inflanty stawały się w ten sposób i ziemią, skąd rozchodziła się złowroga ekspansja niemiecka, i symbolem potęgi państwa Jagiellonów, i figurą trudnej wspólnoty wielu kultur, które spoić chciano religią, językiem, federacyjno-unijnym ustrojem

21 Tamże, wykład XXXVIII, s. 541.

22 Kwestię stosunku Mickiewicza do jezuitów i ich wpływu na upadek Polski interesująco podnosił Stanisław Szczepanowski: Idea polska wobec prądów kosmopolitycznych, Lwów 1901. 
państwa. W końcu, po przedstawieniu jego upadku, Mickiewicz podjął próbę zarysowania horyzontu istnienia nowego państwa - nazwijmy je roboczo „Rzeczypospolitej Wielu Narodów”, której częścią miały być w przyszłości także Inflanty Polskie (a może, jak zobaczymy, Inflanty w ogóle).

U Mickiewicza zarysowuje się wyraźny ciąg ujęć tematu łotewskiego:

- „Starożytni” Lettowie, pobratymcy Litwinów i Prusów w ramach bałtyckiego „Narodu Litewskiego”.

- Ziemie łotewskie jako przestrzeń starcia żywiołów kulturowo-politycznych: litewsko-polskiego, niemieckiego, ruskiego.

- Mieszkańcy Inflant i Inflant Polskich jako obywatele Rzeczypospolitej w XVII i XVIII wieku.

- Ziemie łotewskie podzielone między Szwecję a Polskę.

- Lud łotewski i „fiński” jako poddany Rosji, zachowujący swe tradycje i język, pomimo germanizacji, polonizacji, szwedyzacji i rusyfikacji, nietworzący bytu politycznego; poddawany protestantyzacji, lecz przynajmniej częściowo wierny katolicyzmowi. Jest on potencjałem mesjanistycznej wizji Mickiewicza; siłą kulturowo-religijną i polityczną, do której pragnie się ododwołać, tworząc obraz przyszłości.

Ta układanka łotewsko-litewsko-fińsko-estońska, pomimo komplikacji nazewniczych, ma jednak dla Mickiewicza ten sam wymiar co dzieje ziem litewskich, białoruskich, ukraińskich ${ }^{23}$. Służy tworzeniu planu uwolnienia się spod kurateli Moskwy i innych zaborców, a potem odbudowy państwa neojagiellońskiego. Jakkolwiek trudno to przyjąć Litwinom z XX i XXI wie$\mathrm{ku}^{24}$, jedynie taki projekt Mickiewicz uznawał za realistyczny. Projekt Mickiewicza, oparty na mesjanizmie, odwołujący się do wizji Boga jako Pana Dziejów, Sprawiedliwego Sędziego i Rozdawcy Misji Dziejowych, zakładał nie tylko polityczno-państwową, moralną, lecz i jeszcze Boską relację między elementami tworzącymi przyszłą Rzeczpospolitą Wielu Narodów. Zakładał oparcie jej na źródle wszystkich praw, konstytucji, ustaw, religii,

23 Częściej mówi się z tego powodu o Rzeczypospolitej Trojga Narodów jako Mickiewiczowskim projekcie odnowienia Rzeczypospolitej (polskiej, litewskiej i ruskiej). Jednak nazwa ta nie obejmuje innych narodów, etnosów, religii, które pisarz wyraźnie chciał włączyć do nowej wspólnoty, w tym Żydów, Ormian, Tatarów.

24 Por. V. Kubilius, Adomas Mickievičius. Poeta ir Lietuva / Adam Mickiewicz. Poeta i Litwa, Wilno/Vilnius 1998. 
ustrojów, czyli na Bogu. Przy okazji tworzenia tego rysu mesjanista i wizjoner przemyśliwał nad dziejowymi mikrohistoriami poszczególnych ziem dawnej Rzeczypospolitej, wydobywając z niepamięci Lettów, Estów, Kurów, Liwonów, czyli ludy, które w XX wieku wypracują formuły niepodległościowe państwa łotewskiego, estońskiego i litewskiego ${ }^{25}$.

Ale jego myślenie szło zawsze jakby dalej. Mickiewicz czytał mapy, sięgał do nich z pasją, choć czasami je też ignorował w wielorakim znaczeniu - oto w prelekcjach paryskich, odwołując się do nich, nie pokazywał ich i nie zamieszczał w edycjach tych wykładów. Czasem też ignorował to, co te mapy przekazywały, by narzucać własne interpretacje realiów i zdarzeń (czynił to, oczywiście, w duchu mesjanistycznego wizjonerstwa). Bywało jednak i tak, że wyciągał z map zimne, chłodne wnioski i te dopiero poddawał ideowej reinterpretacji. Tak stało się w ostatnim za życia pisarza tekście przenoszącym nas w naddźwińskie rejony.

W 1854 roku, gdy już słychać było zapowiedzi wojny krymskiej (18541856) ${ }^{26}$, Mickiewicz napisal - zapewne dla francuskiego cesarza Napoleona III - [Notę o położeniu Rygi jako podstawy działań wojennych na wybrzeżach Bałtyku ${ }^{27}$. Pisarz żywił nadzieję na uruchomienie frontu północnego, bałtyckiego w wojnie z Imperium Rosyjskim. Istniały do tego pewne podstawy, bo flota brytyjska i angielska, która wpłynęła na Bałtyk, patrolowała Zatokę Fińską. Antyrosyjscy koalicjanci byli już, jak się wszystkim zdawało, na rogatkach Petersburga. Obóz emigracyjny Hotelu Lambert żywił nadzieję na uderzenie sprzymierzonych na Rosję od strony Bałtyku (oprócz drugiego uderzenia ze strony Turcji, Morza Czarnego). Niestety, działania te ograniczyły się do zdobycia twierdzy Bomersund na Wyspach Alandzkich, pokwitowanego literacko łacińską odą Mickiewicza do Napoleona III ${ }^{28}$. W 1854 roku polski wieszcz

25 Wydaje się, że w szerokiej perspektywie Mickiewicza nie do pomyślenia był polityczny separatyzm łatgalski czy kaszubski, żywy w XXI wieku na Łotwie.

26 Zob. M. Klimecki, Wojna krymska 1853-1856, Warszawa 2014; O. Figes, Wojna krymska 1853-1856. Ostatnia krucjata, Oświęcim 2018.

27 A. Mickiewicz, [Nota o położeniu Rygi jako podstawy działań wojennych na wybrzeżach Bałtyku], [w:] tegoż, Dzieła..., wyd. cyt., T. XII: Legion Polski. Trybuna Ludów, opr. S. Kieniewicz, przeł. L. Płoszewski, A. Górski, S. Kieniewicz, Warszawa 1997, s. 303-306 i 437.

28 Chodzi o łaciński wiersz: Ad Napoleonem III Caesarem Augustum. Ode in Bomersundum captum. 
wierzył jednakowoż, iż lada chwila wybuchnie równocześnie na północy i na południu wielka wojna z Imperium ${ }^{29}$.

Tak zrodziła się [Nota o położeniu Rygi...] Znakomicie pokazuje ona rozmach myśli Mickiewicza. Od wizji znanego mu świata śmiało przechodzi on do planów geopolitycznych, militarnych, strategicznych. Czytelnik przyzwyczajony do obrazu wieszcza-pięknoducha $\mathrm{z}$ trudem odkrywa tekst pisany raczej w gabinecie szpiega, generała czy agenta politycznego (ale, co jasne, z mesjanistyczną nadbudową). Spory fragment analizy Mickiewicza musi zostać tu przywołany:

Jest wiele miejsc warownych na tym wybrzeżu; ze względów, o których poniżej, sądzimy, że Ryga jest tym miejscem, którego położenie przedstawia dla państw zachodnich punkt oparcia, obóz warowny i wyborną podstawę operacyjną: warunki nieodzowne do skutecznego działania na samo centrum państwa rosyjskiego.

Wybrzeże, na którym leży Ryga, zamieszkane jest przez ludność nie mającą nic wspólnego z Rosjanami. Szlachta i mieszczaństwo krajowe są pochodzenia niemieckiego, lud jest fiński. Religia jest tam protestancka. Szlachta długi czas służyła Rosji wiernie; jednak w czasach ostatnich narzucanie przez rząd odmiennej wiary tudzież zarządzenia skarbowe, o których tu rozpowiadać byłoby za długo i zbytecznie, wywołały w końcu niezadowolenie nawet szlachty. Co do ludu, ten zachował się z dala od wszelkich wpływów; toteż armia obca, która by wylądowała w tych stronach, jeśliby nawet zrazu nie spotkała się z życzliwością, to na pewno nie natrafiłaby na opór polityczny. Wystarczy przypomnieć wojnę 1812 roku. Korpus armii francuskiej i sprzymierzonych, który operował w tym kraju, nie musiał tu nigdy walczyć ani z partyzantami, ani z powstańcami. A to, co mówimy o kraju, którego stolicą jest Ryga, da się zastosować w ogóle do całego wybrzeża Bałtyku: do Estonii, jak i Kurlandii. Estonia jednakowoż ze swoją stolicą Rewlem nie ma tak centralnego położenia, aby dać temu, kto ją opanuje, środki działania równie skuteczne jak te, które zapewnia Ryga, ściągająca ku sobie cały handel Estonii i prowincji położonych po tej stronie Dźwiny, to znaczy Inflant, Kurlandii, Litwy. Ryga jest składem handlowym całego tego obszaru. Mieszkańcy całego wybrzeża pozostają w ciągłych stosunkach gospodarczych, a wskutek tego

29 Por. tom: Polacy $i$ ziemie polskie $w$ dobie wojny krymskiej, red. J. W. Borejsza, G. Bąbiak, Warszawa 2008. 
w poczuciu spólnoty politycznej z wielkimi domami handlowymi i wpływowymi osobistościami Rygi. Wiadomość o zajęciu Rygi przez armię cudzoziemską znajdzie oddźwięk wśród całej ludności wybrzeża i poruszy do głębi Litwę 30 .

Miejscem uderzenia na Rosję miała być Ryga. Kierunkiem: ziemie w górę Dźwiny, to jest okolice Dyneburga i Rzeżycy. Zauważmy frazę kluczową: „samo centrum państwa rosyjskiego”. Łotysze, Estończycy, Kurlandczycy i Litwini znajdują się w samym sercu wrogiego Imperium. Zwraca uwagę pewna świadomość etnicznego i historycznego zróżnicowania ziem łotewskich. Czytaliśmy już o Liwonii, wspomnijmy wyodrębnioną tu Kurlandię (nie ma tylko Łatgalii). Jednak to nie zróżnicowanie ziem, ale warunki geograficzne, etniczne i społeczne są podstawą rachub geopolitycznych. Przede wszystkim Mickiewicz oddziela zniemczone i zruszczone mieszczaństwo i arystokrację od ludu „fińskiego”, wprawdzie sprotestantyzowanego, ale żyjącego w odosobnieniu, niewrogiego. Fiński znaczy tu i łotewski, i zapewne estoński (liwoński) ${ }^{31}$. To serce imperium od Estonii po Kurlandię jest więc jeśli nie gotowe na przyjęcie wojsk inwazyjnych, to przygotowane przez swą pogmatwaną historię do tego, by przyjąć bez oporu obce wojska. Jakże nowocześnie Mickiewicz uwypukla w tym miejscu aspekt propagandowy inwazji, bliskie położenie Petersburga. Co też budzi zastanowienie, to wyznaczenie linii ataku od Rygi wzdłuż Dźwiny aż po Psków, ataku mającego na celu odcięcie stolicy od ziem dawnej (przyszłej) Rzeczypospolitej:

Nam osobiście niepodobna podać doraźnie planu ataku na Rygę. Mówiono lat temu dwadzieścia, że flota w towarzystwie flotylli kanonierek mogłaby łatwo zniszczyć forty i baterie broniące ujęcia Dźwiny i że armia lądująca nie natrafiłaby na wielkie przeszkody przy zajmowaniu miasta; że gdyby się tam umocniła, trzeba by regularnego oblężenia, aby ją wyprzeć, pozycja ta bowiem jest broniona od strony lądu przez nieprzerwany łańcuch fortów i bateryj; otóż podaliśmy już przyczyny, dla których oblężenie takie byłoby możliwe tylko w cieplejszej porze roku.

30 A. Mickiewicz, [Nota o położeniu Rygi...], wyd. cyt., s. 304.

31 Podobnie objaśniają edytorzy tekstu z Wydania Rocznicowego 1798-1998, s. 438: „23-4 lud jest fiński - Sformułowanie nieprecyzyjne. Do grupy ugrofińskiej należy język estoński. Język łotewski, podobnie jak litewski, należy do grupy języków bałtyckich”. 
Miasto to mogłoby posłużyć za świetną podstawę operacyjną. Ryga leży u ujścia Dźwiny. Rzeka ta oddziela Inflanty i całe północne wybrzeże od Kurlandii i Litwy; przez Rygę właśnie przechodzi wielki trakt komunikacyjny między Petersburgiem a Kurlandią, Litwą i Polską. Brzegi Dźwiny przedstawiają punkty strategiczne dużej wagi, takie jak Wolmar, Wenden i wiele innych mniejszych miast z ich dawnymi obwarowaniami, dziś w stanie zniszczenia, które panują nad brodami i przeprawami tej rzeki ${ }^{32}$.

Mickiewiczowska analiza geostrategiczna idzie jeszcze dalej: owo północne uderzenie - przy obojętności lub cichym wsparciu protestanckich chłopów i niektórych mieszkańców Rygi - miałoby wywołać wydarzenie zasadnicze, czyli masowe powstanie przeciw Rosji na wszystkich ziemiach północnowschodnich dawnej RP:

Można niewątpliwie liczyć na to, że wszyscy żołnierze pobrani z dawnych prowincji polskich bliskich teatrowi wojny, jak z Kurlandii, Litwy i Białorusi, uciekaliby z wojska masami.

Co do Litwy, ta powstanie na pierwszy strzał armatni. Wszak to ta sama Litwa po dziś dzień, która podczas wojny roku 1831 pierwsza chwyciła za broń i toczyła z Rosją wojnę ludową z taką zaciętością. Powstaniu litewskiemu brakowało jednak naówczas punktu oparcia, warownego obozu, odwodów. Wszystkie te korzyści znalazłoby ono w razie zajęcia Rygi przez armie sprzymierzone ${ }^{33}$.

Dezercja z armii rosyjskiej, powstanie na Litwie, obecność wojsk aliantów w Rydze i nad Dźwiną - wszystko to miało odwrócić geostrategiczne położenie Rzeczypospolitej i pognębić Imperium. Nowoczesna wojna - z bitwą morską, desantem, dezercją i sabotażem - wszystko to Mickiewicz zarysował przed cesarzem Francuzów i politykami znad Sekwany, powołując się na niewykorzystane szanse historyczne kampanii Napoleona (1812) i powstania listopadowego na Litwie (1830). Nie mamy dowodów, iż memoriał poety wywarł jakikolwiek wpływ, że wywołał oddźwięk. Państwa zachodnie, jak prawie zawsze, ograniczyły się do rozbudzenia nadziei w egzotycznych dla nich krainach

32 A. Mickiewicz, [Nota o położeniu Rygi...], s. 304-305.

33 Tamże, s. 306. 
wschodnioeuropejskich i ich mieszkańcach ${ }^{34}$. Czyż można było wymagać od Napoleona III, by rozróżniał Kurlandczyka od mieszkańca Rygi, wiedział, co kryje się pod wyrażeniem „lud fiński”, albo pamiętał mapy Inflant Polskich i północnych prowincji upadłego państwa?

Z wywodów Mickiewicza dla opowieści o Łotwie i Łotyszach wynikają jednak ważne wnioski. Spojrzenie Mickiewicza nie kończy się na przeszłości Lettów, Liwonów, Kurlandczyków. Obejmuje realia połowy XIX wieku i sięga w przyszłość. Towarzyszy mu świadomość silnego w tym stuleciu zróżnicowania etnicznego i religijnego ziem nad Dźwiną, przy czym zasadnicza (wciąż!) była dlań linia podziału, jaką wytyczała granica dawnej Rzeczypospolitej, w której swe miejsce mieli Kurlandczycy i Inflantczycy (tu jakby pisarz nie widział podziału na lud i szlachtę, rody arystokratyczne) $)^{35}$. Zastanawiający jest życzliwy opis „ludu fińskiego” z ziem odpadłych od Rzeczypospolitej po pokoju oliwskim (1660), wyraziście przeciwstawianego mieszczaństwu i arystokracji podlegającym wpływom obcym.

Najpoważniejszy wniosek (czy najistotniejsza przesłanka) myśli geopolitycznej Mickiewicza wypowiedziany został jakby mimochodem. Otóż jest to myśl, że ziemie nad Dźwiną (Łotwa), Estonia i Litwa są w miejscu na mapie, które musi budzić najżywszą czujność i w konsekwencji agresję Imperium. Są jak cierń w torsie Cesarstwa; położone tuż pod jego stolicą, tuż nad brzegiem Bałtyku, od którego odgradzają Rusinów ${ }^{36}$. Wypędzenie Bałtów i Finów z ich ziem stanowi - jak to dzić widać - warunek sine qua non istnienia mocarstwa w XIX- i XX-wiecznym kształcie. Jest to również fundament rachub geopolitycznych i wizji mesjanistycznych Mickiewicza - ziemie te stanowią ich strategicznie ważną część. Ale też nie sposób - nawet odrzuciwszy rozważania polskiego poety-polityka, myśleć o samostano-

34 Wiedza o Europie Środkowej i Wschodniej, a już szczególnie jej kulturze, jest na Zachodzie nikła także w XXI wieku. Zob. deziluzyjny artykuł francuskiego badacza: G. Métayer, Musimy wspólnie przepracować „pęknięcie” Europy, „Wszystko Co Najważniejsze. Idee. Opinie. Debaty" 2019, nr 13, s. 8.

35 Widać tu zresztą partykularyzm tego myślenia: co przeszkadza poecie-strategowi w części Inflant straconej po pokoju oliwskim, czyli podział miedzy ludem a szlachtą i mieszczaństwem, to zdaje się nie istnieć w Inflantach Polskich. Mickiewicz czasem idealizuje rzeczywistość społeczną, dopasowując ją do oczekiwań własnych, oczekiwań mesjanisty.

36 Zob. P. Eberhardt, Koncepcje geopolityczne Aleksandra Dugina, „Przegląd Geograficzny" 2010, nr 2, s. 221-240. 
wieniu, kulturowym przetrwaniu ludów z tych ziem bez geostrategicznych planów konfederacji, unii, sojuszu. Bez takiego aliansu ponad różnicami, to mówi nawet Mickiewicz, nikt nie oprze się sile Rosji, dążącej nie tylko do opanowania ziem, lecz też wyniszczenia obcych etnicznie i mentalnie nieskolonizowanych autochtonów.

Mickiewiczowski kraj Lettów ledwie wyłania się z pomroku dziejów, a od razu staje się kluczowym miejscem wielkiej światowej polityki. Jest już terytorium, lud jeszcze czeka, by ujawnić swą tożsamość i głęboką pamięć. W każdym razie z punktu widzenia poety najważniejsze okazało się to, że ani lud fiński, Lettowie, ani Kurlandczycy, Inflantczycy i Litwini nie podzielili losu bałtyckich Prusów, którzy zniknęli z teatru dziejów, zostali pokonani. „Lettowie" stanowili więc swoisty potencjał przyszłości, na który poeta liczył.

Piszę słowo „Lettowie” w cudzysłowie, bo doprawdy trudno czasem panować nad terminologicznym zamętem, jaki pojawił się u Mickiewicza. Choć warto docenić przyczynę tego zamętu: pisarz-strateg nie wrzuca wszystkich do jednego worka, nowocześnie zdaje sobie sprawę z tego, że trzeba odróżnić Kurlandczyka od Letta, mieszkańca Rygi od mieszkańca Rewla (Tallina), a lud fiński od litewskiego.

Tu już wkracza nowoczesność - jej znakiem nie są narodziny narodów w XIX wieku, jak się bezmyślnie twierdzi. Dla Mickiewicza, Goethego i Puszkina takie twierdzenie byłoby obrazoburstwem - ich narody, sądzili, miały wielowiekowe dzieje i starą pamięć historii ${ }^{37}$. Symptomem tej nowoczesności jest proces krystalizowania się ostatnich ethnosów, pamięci historycznych, które czekały na swój moment dziejowy (wiek XIX), a czasem czekają do wieku XXI ${ }^{38}$. To właśnie jest nowoczesność Łotyszów, Litwinów, Estończyków, Ukraińców, Rumunów, Słowaków i innych. Spór o „innych”, którzy chcą być narodem, rozpali drugą połowę dziewiętnastego stulecia i wybuchnie w wieku XX.

Poniekąd ta historia ziem nad Dźwiną - tak a nie inaczej postrzeganych przez Polaka - trwa w najlepsze w stanie wrzenia w XXI wieku.

37 Por. T. Kostkiewiczowa, Memozyne i córki. Pamięć w literaturze polskiej drugiej połowy XVIII wieku, Toruń 2019, Rozdział II i III.

38 Pisząc o procesach, które wciąż nie kończą sie sukcesem, mam na myśli Białoruś. Zob. A. Nowak, Metamorfozy Imperium Rosyjskiego 1721-1921, Kraków 2018. 


\title{
Biograficzne dopowiedzenie
}

Mickiewicz miał, dodajmy, niebłahe powody, by na ziemie łotewskie patrzeć ze szczególnym zainteresowaniem - były to też powody osobiste. Ziemie Wielkiego Księstwa Litewskiego, obejmujące XIX-wieczne Litwę i Białoruś, traktował jako część Polski, która jest jego głębinną, duchową ojczyzną. O niej, o powrocie do Litwy, kątka litewskiego, pisał do końca życia. Niewątpliwie częścią tej przestrzeni były dlań Inflanty Polskie z Rzeżycą i Dyneburgiem. Ich przestrzeń wypełniał przecież jeśli nie ten sam, to podobny, północno-wschodni krajobraz, jakże ważny dla Mickiewicza jako wyobrażenie spokoju, harmonii natury połączonych $\mathrm{z}$ tradycją $\mathrm{i}$ historią jego ojczyzny. Wyobrażenia te $\mathrm{w}$ dojrzałej twórczości nabrały cech eschatologicznych, stały się symbolizacjami zbawczego ukojenia, spełnienia, raju.

Z ziemią inflancką Mickiewicz przez lata łączył obraz „Litwinki” - Emilii Plater (1806-1831), bohaterki powstania listopadowego, zamknięty w pięknej, lirycznej opowieści, uwznioślającej i mityzującej:

\author{
Lecz ten wódz, choć w żołnierskiej odzieży, \\ Jakie piękne dziewicze ma lica? \\ Jaką pierś? - Ach, to była dziewica, \\ To Litwinka, dziewica-bohater, \\ Wódz Powstańców - Emilija Plater! ${ }^{39}$
}

Nieprawdą jest jednak - to temat na inną opowieść - jakoby poeta uczynił z Emilii Plater (po matce von der Mohl!, pannie ze znanego inflanckiego rodu) kogoś, kim nie była: kobietę żołnierza, która zginęła w walce. Nic takiego nie mówi Śmierć Pułkownika! Przeciwnie, Mickiewicz dobrze znał okoliczności jej śmierci, co potwierdza opinia wygłoszona w Collége de France o ,młodej i delikatnej pannie, pochodzącej z arystokratycznego rodu, która podniosła powstanie w swym powiecie” i która „zmarła z trudów i wyczerpania”40. Co znaczące, jeszcze później, w okresie towianistycznym, wieszcz uczynił z Emilii Plater

39 A. Mickiewicz, Śmierć Pułkownika, [w:] tegoż, Dzieła..., T. I: Wiersze, opr. Cz. Zgorzelski, Warszawa 1993, s. 347.

40 Pisząc o procesach narodotwórczych, które wciąż nie kończą sie sukcesem, mam na myśli Białoruś. Zob. A. Nowak, Metamorfozy Imperium Rosyjskiego 1721-1921, Kraków 2018. 
wzór aktywnej kobiety, uduchowionej i „zdolniejszej” do „zasiadania w radach, rządach, tak rozumem, jak siłą ducha, od wielu mężczyzn!”41. Ta uduchowiona Mickiewiczowska emancypantka miała więc stać się wzorem dla tych wszystkich kobiet i mężczyzn, którzy powstać mieli na przykład na sygnał nowego powstania. W [Nocie o położeniu Rygi...] widzieliśmy jeden z planów, wariantów militarnych i społecznych kolejnej insurekcji. Jej impulsem miał być atak morski koalicji antycarskiej w okolicach Rygi, marsz wojsk w górę Dźwiny i finalnie wielkie powstanie na Litwie. Na Litwie, czyli także w Inflantach Polskich.

Ostatni kontekst, jak mniemam, również jest istotny. Z tegoż samego rodu inflanckiego Platerów wywodziły się dwie postaci kluczowe dla życia polskiej Wielkiej Emigracji. To bracia: Władysław Broel-Plater (1808-1889) i Cezary Plater (1810-1869). Ten drugi na emigracji współtworzył Towarzystwo Litewskie i Ziem Ruskich, należał do obozu Hotelu Lambert księcia Adama Czartoryskiego, a wraz z Mickiewiczem podpisał akt zawiązania koła „Braci Zjednoczonych”, z których grona - wokół „domku” Bohdana Jańskiego - uformuje się sławny zakon zmartwychwstańców ${ }^{42}$. Cezary przeżył zresztą duchowy przełom, gdyż po hulaszczej młodości przeszedł na pozycje religijne i konserwatywne. Wspierał Mickiewicza, zabiegając o druk dzieł, które, jak Historię polska ... wieszcz miał napisać.

Pierwszy z braci Platerów, Władysław, związany był z Mickiewiczem równie mocno. Potomni zapamiętali go jako założyciela polskiego Muzeum w Rapperswilu. Jak brat Cezary, był Władysław zaangażowany w oba powstania. Mickiewicza poznał w 1829 roku w Dreźnie, zrazu relacje te układały się dobrze. Władysław zaangażował się na początku prelekcji paryskich w stenografowanie wykładów wieszcza (robił to najpierw sam, potem wynajął stenografa), jednak gdy Mickiewicz przystąpił do Koła Sprawy Bożej Andrzeja Towiańskiego, Plater stał się jego zażartym, osobistym przeciwnikiem ${ }^{43}$.

41 Tegoż, Dzieła..., Pisma towianistyczne. Przemówienia. Szkice filozoficzne, opr. Z. Trojanowiczowa, Warszawa 2001.

42 O Cezarym Platerze zob. S. Kieniewicz, Palter (Broel-Plater) Cezary Augustyn (1810-1869), [w:] Internetowy Polski Stownik Biograficzny: https://www.ipsb.nina.gov.pl/a/ biografia/cezary-augustyn-plater [dostęp: 15.01.2019].

43 O Władysławie Platerze por. S. Kieniewicz, Plater (Broel-Plater) Władysław Ewarysty (1808-1889), [w:] Internetowy Polski Słownik Biograficzny, https://www.ipsb.nina.gov. pl/a/biografia/wladyslaw-ewaryst-plater [dostęp: 15.01.2019]. 
Trudno mieć wątpliwości, że prawie trzydziestoletnie zawiązki Mickiewicza z przedstawicielami znamienitego rodu Platerów nie miały wpływu na jego postrzeganie Inflant Polskich i w ogóle ziem łotewskich. Omawiana tu [Nota...] pokazuje, iż było to spojrzenie na dwie części Inflant - i tę polską, i tę szwedzką (a potem rosyjską). W sumie obie stały się już w XIX wieku posiadłościami Imperium o strategicznym położeniu. Myślenie Mickiewicza było naraz i etnocentryczne (uwzględniało tradycję i język ludu tej ziemi), i polonocentryczne (opierało się na planach wielkiego powstania antyrosyjskiego). Obie perspektywy spinało piękne (w owych czasach) marzenie Rzeczpospolita Wielu Narodów, której przynajmniej częścią miały być dawne Inflanty Polskie.

\section{Bibliografia}

Mickiewicz A., Powieści poetyckie, Warszawa 1978.

Mickiewicz A., Dzieła. Wydanie Rocznicowe 1798-1998, T. I, VIII-IX, XIII, Warszawa 1993-2001.

Zajas K., Nieobecna kultura. Przypadek Inflant Polskich, Kraków 2008.

Ławski J., Litwy Mickiewicza, [w:] Tożsamość na styku kultur, T. 3, red. I. Masojć, H. Sokołowska, Wilno 2016.

Maślanka J., Mickiewicz o despotyzmie rosyjskim, [w:] tegoż, Szkice z dziejów literatury i kultury. Idee - motywy - wartości, Kraków 2014.

Zubiński T., Historia literatury łotewskiej i łatgalskiej, Sandomierz 2014.

Prusinowska J., Przez otwór w beczce: Łotwa postkolonialna według Agnese Bule, „Porównania” Vol. 14/2014.

Rączka T., Inflanckie pitoreski. Kultura dworu ziemiańskiego dawnych Inflant Polskich w XIX wieku, Warszawa 2019.

Vaverne V., Wpływy polskie w literaturze łotewskiej (od połowy XIX w. do 1940 r.), [w:] Kultura polska na Łotwie. Polu kultura Latvija, Ryga 1994.

Łotwa - Polska. Materiały z międzynarodowej konferencji naukowej, Ryga 1995. 